\title{
The Relationship between Store Brand and Customer Loyalty in Retailing in Malaysia
}

\author{
Rahman Bin Abdullah (Corresponding author), Norhanisah Bte Ismail, Akmal Fadhila Bte Abdul Rahman, \\ Musnadzirah Bte Mohd Suhaimin \& Siti Khadijah Bte Safie \\ Faculty of Hotel and Tourism Management, Universiti Teknologi MARA \\ Dungun, 23000, Terengganu, Malaysia
}

Tel: 60-9-840-1283 E-mail: rahma255@tganu.edu.my

Mohd Tajul Hasnan Mohd Tajuddin

Faculty of Accountancy, Universiti Teknologi MARA

23000 Dungun, Terengganu, Malaysia

Tel: 60-9-840-1292 E-mail: tajulhasnan@tganu.uitm.edu.my

Radzuan Noor Armia, Nik Adnan Nik Mat \& Nazarudin Derani

Faculty of Hotel and Tourism Management, Universiti Teknologi MARA

Dungun, 23000, Terengganu, Malaysia

Tel: 60-9-840-3849,60-9-840-1913 E-mail: radzuann@tganu.edu.my, rahma255@tganu.uitm.edu.my

Mohamed Muneer Samsudin \& Razlan Adli Zain

Faculty of Hotel and Tourism Management, Universiti Teknologi MARA

Dungun, 23000, Terengganu, Malaysia

Tel: 60-9-840-3822, 60-9-840-1711Ｅ-mail: muneer@tganu.edu.my, radzlan@tganu.edu.my

Gopala Krishnan Sekharan Nair

Academy of Language Studies, Universiti Teknologi MARA (UiTM)

Dungun Campus, 23000 Dungun, Malaysia

Tel: 60-9-8400-8225Ｅ-mail: gopal792@tganu.uitm.edu.my

Received: April 10, 2011

Accepted: September 15, $2011 \quad$ Published: February 1, 2012

doi:10.5539/ass.v8n2p171

URL: http://dx.doi.org/10.5539/ass.v8n2p171

\begin{abstract}
Purpose: The purpose of this study are to ascertain the linkages between brand and customer loyalty towards store brands especially in Malaysia, to investigate the factor that contributes to brand loyalty to increase the number of brand loyal customer and to determine the factors influencing the success of store brand in the market.

Significance of the study (Theoretical aspect): It is hope that this research may create a niche understanding of a relationship between store brand and customer loyalty in Malaysia. The findings of this study also can be added into current knowledge and literature for future reference.
\end{abstract}


Significance of the study (Practical aspect): This research is also essential in practical aspect where it can be used as a guideline for the newly developed company to market their store brand. Furthermore, the findings of this study can also be used by other organization to solve problems occur in the future resulting from aggressive competition in the market. Hence, they may improve their performance in providing the best product or service to customers. Besides, this study also will ensure that the attributes of customer loyalty strategies and customer loyalty program can be implemented in the store brand business such as Mesra reward card and Giant membership card.

Keywords: Customer loyalty, Branding, Private label, Retailing, Store brand

\section{Introduction}

Today, as markets become more aggressive and competitive, many organizations realize the significance of retaining existing customers and some of them have came out with a variety of activities to build a long term relationship or in other words loyalty in their customers. In general, Uncles et al. (2003) defined loyalty as something that customers may demonstrate to brands, activity, services, product categories or stores. They also added loyalty is mainly a positive attitude towards brand that sometimes may lead to a connection with it. According to Yen and Gwinner (2003), the main driver to a consumer decision for joining into and preserving a long term relationship with an organization is their evaluation of the organization's core product or services and the relational characteristics of the exchange. Moreover, Oliver (1997) stated, allegiance or loyalty is a deep held dedication to repurchase or re used a particular product or services in the future consistently and automatically causing repetitive same brand purchasing.

At present, most of retailers are likely to develop store brand as it has high potential in obtaining loyal customers. Besides, brand is one of many factors that may influence customer's purchasing behavior because of the uniqueness and specialty of the product. Store brand can be determined as private label, own label or retails brand as noted by Huang and Huddleston (2009). A good brand name or symbol should be able to deliver product image to its customers and has value added in it. As stated by Palumbo and Herbig (2000), an excellent store brand should be identifiable and recognizable by customers, which highlight important characteristics such as quality and value of the product. Furthermore, there are plenty of store brands in the market today that serve customers a variety of choices. So, retailers should be more creative and innovative in developing store brand in order to attract customers and differentiate their product with competitors.

However, the linkages between stores branding and customer loyalty in terms of private label branding products in retailing still possess a vague picture in Malaysia. Consumers in Malaysia are hypothesized to purchase private label branding due to pricing instead of being loyal to these brands. This research is conducted in order to ascertain the relationship between store brand and customer loyalty in retailing in Malaysia.

\section{Literature Review}

\subsection{Store Brand}

Store brands are the most successful brands in the world. In general, it is considered as commodities owned, private-labeled and established by companies where their main economic obligation is distribution as compared to manufacturing (Schutte, 1969). Nowadays, there are many well established store brands in the world such as Tesco, Carrefour, Target, Wal-Mart, PARKnSHOP and Kmart. Tesco as one of the leading food retailer in Europe had gone through an incredible growth during the 80s. On the other hand, a France origin store brand, Carrefour has developed many types of food product such as yogurt, cereal and pasta. Furthermore, Target and Wal-Mart are the most popular retailers in the United States. Target offers a variety of store brands like household and beauty product while Wal-Mart has produced grocery products' brands like Great Value and Sam's Choice. PARKnSHOP is known to be a leading retailer in Hong Kong that sells grocery product and lighting equipment whereas Kmart provides products like snacks, beverages and household products.

\subsection{History of Store Brand}

According to Herstein and Gamliel (2004), a scenario of the retailing phenomenon discovers five eras in the history of store brands which (1) the starting of store brands in the industry (1840-1860); (2) the power and influence of store band decline (1861-1928); (3) store brand's reemergence and ascend (1929-1945); (4) store brand become stable in the market for two decades (1946-1975); and (5) intense competition between store brands and national brands era (1976-present). 


\subsection{Elements in Store Brand}

Based on research, there are few elements associated with store brand such as price and perceived quality, brand image and innovation.

\subsubsection{Price and Perceived Quality}

Price and perceived quality are considered to be related with each other as stated by Elliot (1996), consumers also consider price discrepancies as quality indication. In general, consumers purchase private label brand because of its slightly lower price rather than the other brand such as national brand. In the other hand, Zeithaml (1988) asserted perceived quality as consumer's perception in relation to product's supremacy or fineness. It is because positive consumer's perception towards store brand is very essential to make them stick with that particular brand. Furthermore, consumer prefers to stay with recognizable name, as brand name brings higher value or perceived quality. Aaker (1991) added, a favorable and excellent store should promise assurance of product's quality. In addition, Azzato (2009) stated lower-income and middle-income households prefer to buy store brand due to its lower price.

According to Dick et al. (1997) private label gives lower price because of the low manufacturing cost. It is due to inexpensive packaging and slightly lower overhead cost. Hence, consumers prefer to purchase store brand because of its cheaper price. Bellizi et al. (1981) and Cunningham et al. (1982) argued that households refuse to purchase store brand as they think that it is poor in quality. Thus, most consumers start thinking that store brands is not good in quality because of the lower price than national brand that gives premium price. Premium price can be defined as a highest price that consumers may pay. But, nowadays we can see that store brand is improving in terms of quality (Dunne and Narasimhan, 1999). So, many manufacturers compete with each other to serve a brand that provides high value but slightly lower in price in order to attract more people. However, most of the retailers claimed that store brand has the same quality level as the national brand but at the lower price ("Target up \& up Brand Offers Great Quality at Lower Prices", 2009; Boyle, 2009).

In addition, Richardson in his previous research asserts that a successful private label depends on the way how retailers deliver product quality rather than low price to its consumers (Richardson et al., 1994). Nevertheless, today's researchers claim that gap in price is no longer an issue in determining the success of store brand in the market (Hoch, 1996).

\subsubsection{Brand Image}

According to Tepeci (1999), a good and strong brand image which comprises of logo, color and motto is very crucial for all retailers and customers to differentiate one product from others. Undoubtedly, people nowadays purchase products based on their preferences and familiarity with particular brand image. As stated by Keller (1993), brand image can be determined as an opinion or awareness of consumers to particular brand that is influence by brand perception in their mind. They will evaluate the product for its quality (Sheinin and Wagner, 2003). Thus, store brand that come with differentiation may gain advantages as consumers nowadays pursue brand uniqueness.

Furthermore, because of special brand image, consumers may recognize that particular product is pleasing compared to its competitor (Schiffman and Kanuk, 1991). For instance, researchers propose that the largest hypermarket, Tesco, to enhance positive and encouraging store image. Based on Martenson (2007), the purpose of it in retailing is to build better consumer's perception towards private label brand. Hence, a pleasing image of own label will creates customer's satisfaction and at the same time leads to store brand loyalty.

\subsubsection{Innovation}

Typically, innovation can be said as an improvement or product's update done by retailer in order to retain their customers. According to Tepeci (1999), consumer's awareness and sensitivity must be taken into consideration before retailers make any changes or innovations on the product. However, there are certain consumers who may accept it and may not. When the innovation does not meet consumer's expectation, the retailers may not be able to deliver the specialty of the product to the consumers (Aaker and Keller, 1990) and also cannot retain brand loyal customer. Tepeci (1999) added that there is a relationship between product innovation and brand loyalty.

Moreover, by creating product differentiation, consumers will have less intention to switch to another brand. Innovation also will make product look different and interesting to be tried by customers and let them shop with 
confidence. So, consumers will enhance the store image that gives the opportunity to the retailers to create brand extension. For instance, British largest hypermarket, Tesco has expended its store in United Kingdom by opening sub-brands such as Florence and Fred (Elms et al. 2010). Stamer and Diller (2006) concluded that retailers or product innovators should seek for new knowledge and understanding about how to innovate store brand effectively regarding to fulfill consumers' demands. Thus, consumers will become loyal to that store brand and always craving for product's innovation. Here, it can be hypothesized that product advancement or differentiation may contribute to brand loyalty.

In light of the above discussion, retailers should be alert of all those elements in order to retain customers. It is because an excellent private label may leads to higher numbers of brand loyal consumers. Besides, they are one of the main foundations contributing to company's revenue. In conclusion, brand loyalty becomes a very essential tool in sustaining loyal customers and to compete with other industry players.

\subsection{Customer Loyalty}

According to Gonring (2008), in the middle 1980s, loyalty was only identified based on product or service quality. However, in the late 1980s, loyalty had slowly transformed into customer driven and in the early 1990s, company started focusing on customers need and responding to their grumbles. In the late 1990s, company focus began to shift to competitors and they tried to produce product through generating latest and distinctive benefit in order to be competitive in the market. Now, in the twentieth century, this concept has evolved to its current stage where customer is their primary target.

In addition, customer loyalty or customer allegiance can be described as a concept that has changed over year. It has a very broad definition and hard to define. Loyalty exists when customer becomes conscious and alert to particular products it may be perceived differently by the customer in term of service. According to Reichheld and Sasser (1990), loyal customer is a customer who continues to maintain a positive behavior towards the service provider. Based on few researchers, there is a significant relationship between loyalty and service quality provided by a company. Getty and Thompson (1994), there is a positive link between customer loyalty and customer satisfaction toward lodging experience and service quality in hotel industry.

\subsection{Elements in Customer Loyalty}

According to few researchers, satisfaction, brand equity, commitment and resistance to change and, trust are elements related to customer loyalty.

\subsubsection{Satisfaction}

There is a consensus amongst practitioners and academicians that customer satisfaction is a necessary precursor of loyalty (Cronin \& Taylor, 1992; Gremler \& Brown, 1997; Fitzel, 1998; Sivadas \& Baker-Prewitt, 2000). There are several researchers that describe satisfaction as an emotion (Westbrook, 1980; Woodruff et al., 1983) whereas other researchers have reduced it to a purely cognitive comparison (Churchill \& Suprenant, 1982; Bloemers \& Kasper, 1995). Oliver (1997) defined customer satisfaction as the consumer's response towards fulfillment, the degree to which the level of fulfillment is pleasant or unpleasant.

Many researchers have proved that there is a positive relationship between satisfaction and loyalty (Oliva et al. (1992); Heskett et al., 1994; Kandampully \& Suhartanto, 2000; Szymanski \& Henard, 2001). Rowley (2005) added satisfied customer is likely to be loyal customer with or without the mediation of other antecedents. However, there are few researchers that disagree since they have proposed several moderators of satisfaction and loyalty which are experience, quality (Oliver, 1993), price (Anderson et al., 1994) and also value that can be defined as the ratio of perceived quality relative to price (Zeithaml, 1988; Dodds et al., 1991; Holbrook, 1994). Here, it can be suggested that, the higher the level of satisfaction in customer, the higher the level of loyalty will be.

\subsubsection{Brand Equity}

In general, brand equity can be described as a value associated to the brand. According to Aaker (1991), brand equity can be defined as a set of brand assets and liabilities that are linked to a brand, its name and symbol which derived from value provided by a product to a company or to that company's buyer. There are many variables which related to brand equity such as public relation, symbols and packages (Aaker, 1991), company image, 
slogans or jingles, warranties (Boulding \& Kirmani, 1993), promotional effect (Keller, 1993), brand-naming strategy (Keller et al., 1998) and promotional effect.

The management and measurement of brand equity remains arguable issues in the marketing literature (Keller \& Lehmann, 2006). According to Aaker (1991), there are four dimensions of brand equity which are brand awareness, brand associations, perceived quality and brand loyalty. Brand awareness can be illustrated as the probability that a brand will appear in mind and the degree to which it does so. In addition, brand associations are everything which is connected to a brand in the customer's memory such as country of origin (Pappu et al., 2007; Yasin et al., 2007), store (Yoo et al., 2000), competitors (Biel, 1993), product (Bullmore, 1984), retailer (Pettijohn et al., 1992; Buchanan et al., 1999), company (Roos-Wooldridge et al., 2004; Blomback \& Axelsson, 2007; Martenson, 2007) or users with certain demographic or lifestyle characteristics (Fournier, 1998; Patterson, 1999).

Perceived quality on the other hand is described as a core aspect in the customer-based brand equity frameworks (Farquhar, 1989; Keller, 1993; Aaker, 1996; Dyson et al., 1996). Keller (1998) and Aaker (1991) added brand loyalty is one of the attributes of brand possessing strong brand equity. In summary, many researchers concluded that there is a strong positive relationship between brand equity and loyalty. Product with high brand equity will lead to customer loyalty.

\subsubsection{Commitment \& Resistance to Change}

Commitment has been recognized as one of the essential mediating variables in developing customer loyalty (Morgan \& Hunt, 1994; Garbarino \& Johnson, 1999). Assael (1987) added brand loyalty can be defined as a commitment to a particular brand or brand-set deriving from certain positive behaviors toward that brand. According to Geyskens et al. (1996), commitment can be divided into two categories which are affective and calculative commitment. Affective commitment is the desire to continue the relationship that has been built between the firm and the customer since the customer already like the firm while calculative commitment refers to the desire to retain a good connection between two parties in order to avoid high switching costs.

Furthermore, Taylor et al. (2004) argued that resistance to change is the basis for commitment as well as the core indication of commitment. In general, resistance to change can be defined as the customers' attitude of refusing to turn to other firm's brand. They also added resistance to change is the key factor to loyalty. In light of the above discussion, regardless to any types of commitment, it can be hypothesized that loyalty is positively linked to commitment and resistance to change.

\subsubsection{Trust}

In general, trust can be defined as a willingness to depend on an exchange party when someone has confident to that party. Trust also refers to an advantage received by consumers in long-term relational exchange with the organization (Gwinner et al., 1998). Many researchers have suggested that trust acts as a mediating variables in the satisfaction-loyalty relationship (Singh \& Sirdeshmukh, 2000; De Ruyter et al., 2001; Chaudari \& Holbrook 2001). However, Berry (1993), Gremler \& Brown (1996) and Taylor et al. (2004) stressed that trust acts as a basis of loyalty creation. Moreover, Morgan and Hunt (1994) also proposed that trust is a precursor to commitment which eventually will lead to loyalty. Here, it can be concluded, trust plays an important role in creating loyal customer.

In summary, it can be concluded that customer loyalty plays a significant role in many businesses since years ago. Therefore, if the company can sustain their customer well, the customers will have less attention to switch to its competitors and keep being loyal to the company and eventually lead to high profitability.

\subsection{Relationship between Store Brand \& Customer Loyalty}

Over the past few decades, retailing has been the biggest single industry in most countries with the grocery sector being the most essential in terms of contributing high volume of profit and value (Ailawadi, 2001). This situation has attracted more retailers entering the industry and caused aggressive competition among them. Due to that, a company's success largely depends on the number of loyal customers in that company. Here, store loyalty can be defined as the repetitive buying behavior for either the same products or any other products at a certain store (Osman, 1983). 
Monroe (1990) asserted that price verifies the product's quality and the willingness to pay for the product (Zeithaml, 1988; Dodds et al., 1991). As noted by Pechmann and Ratneshwar (1991), consumers perceive product quality based on its price. In the other words, product with high price will provide high quality value and vice versa. However, Richardson et al. (1994) argued, there are no gaps in quality of store brand and national brand although there is a difference in price. This can be proved by previous researches which in assuring products' quality, information and prior knowledge of product are more important than price. In addition, Kwon (1990) noted, store brands with good image are more favorable and create more loyal customers rather than store brands with less positive image. This is because brand image will influence them in selecting good brand (Dolich, 1969). Johnson and Puto, (1987) added, brand image also may manipulate customers' purchasing behavior. Therefore, a superior brand image will remain in their mind and enable them to differentiate the brand and eventually contributes to loyalty.

Moreover, Reda (2002) suggested that store brands help department stores in distinguishing their products and increasing their sales revenue. Similarly, by creating something new to the product, retailers may gain double profit and finally builds long term relationship with the customers. Due to that, there are lots of retailers today continuously doing research regarding on several ways in improving quality of the store brand (Tajeddini, 2011). Thus, innovative or differentiated products have to be distinctive in the market in order to gain more satisfied customers (Holbrook and Hughes, 1998).

In general, loyalty and repurchase behavior are influenced by consumers satisfaction (La Barbera and Mazursky, 1983) that leads to low intention to switch to another brand. Additionally, customers tend to be satisfied when their needs and wants are fulfilled by the retailer. According to Pepe et al. (2011), in the previous study it was verified that satisfaction is really affecting repurchase intention. Hence, retailers should determine the driver that enhances customer satisfaction which leads to loyalty.

Furthermore, Ambler (1997) typically stated that customer loyalty has a positive relationship with brand equity and brand image (Nielsen, 1992). Hence, a store brand with high brand equity will be very useful in gaining more brand loyal customers. Ambler also added customers' habit and attitude towards a particular brand will enhance the store's future profit.

In addition, Bloomer and Kasper (1995) found that loyalty entails repetitive purchasing through a high commitment towards a certain products. Thus, commitment emerged when customers think that the connection with retailer is essential in sustaining it in the long term period. Consumers usually preserve a business relationship with the retailer because they want (affective commitment), need (calculative commitment) or supposed (normative commitment) to do so (Meyer and Allen, 1991; Gundlach et al, 1995). Moreover, commitment also acts as a useful construct in measuring the level of customer loyalty and forecasting future purchase frequency behavior (Dwyer et al., 1987; Morgan and Hunt, 1994).

Incidentally, past researchers have shed light that customer trust to store brand influence store patronage because it positively related to perceived value and intention to be loyal (Guenzi et al. 2009). Here, it can be illustrated that when customers have trust towards a particular product, they will become loyal to that brand since they perceived high value from it. Crosby et al. (1990) added that trust essentially influence commitment and building intentions to continue long term relationship with the retailers. In summary, establishing a loyal customer base should become the ultimate goal of any business in order to ensure the profit and longevity of the business.

\section{Findings}

According to Elliot (1996), consumers usually use price gap as a quality indication. Furthermore, for them, a recognizable name becomes a consideration when thinking about the quality of certain brand. Azzato (2009) noted that most of household purchase store brand because of its inferior price. In addition, consumers perceived that store brand and national brand are same in terms of quality but store brand offers a little bit lower price. However, based on Bellizi et al. (1981) and Cunningham et al. (1982), households not choosing store brand as it gives lower price. Thus, they perceived that store brand is poor in quality. Basically, consumers tend to purchase store brand because of preference and familiarity of one's brand. Shiffman and Kanuk (1991) asserted that a brand with good image will be more pleasing compared to others. Besides, brand image also helps to grow more consumer perception towards store brand. Moreover, innovation also has a positive relationship with loyalty. Consumer awareness and sensitivity are two things that need to be considered when making an innovation to 
products (Tepeci, 1999). Hence, retailers may lower consumer intention to switch to another and might give them a chance to create brand extension. Conversely, Aaker and Keller (1990) noted that retailer may not be able to convey the uniqueness of the product if it is not suit to consumer's expectation.

Based on the research by Oliver (1997), he asserted that a satisfy customer will respond when their needs are fulfilled by retailers and thus, will create loyalty. However, in previous research, there are some mediators that influence the relationship between satisfaction and loyalty which are experience, quality, price and value (Oliver, 1993; Anderson et al., 1994; Zeithaml, 1988; Dodds et al., 1991 and Holbrook, 1994). Based on Aaker (1991) and Keller (1998), brand equity consists of brand awareness, brand association, perceived quality and brand loyalty contributes to brand loyalty. They end up with conclusion that there is a positive relationship between brand equity and customer loyalty. According to Geyskens et al. (1996), commitment which comprises of affective, normative and calculative commitment contributes to customer loyalty towards one brand. Nevertheless, resistance to change can be considered as foundation of commitment (Taylor et al., 2004). Gwinner et al., (1998) noted that when consumers trust to one brand, they may enjoy the benefits for being loyal, but Morgan and Hunt (1994) asserted that trust is one of the antecedents which lead to satisfaction, then to loyalty.

\section{Discussion and Conclusion}

Nowadays, there are lots of store brands emerge in the Malaysian market such as Giant, Carrefour and Tesco. This is because store brand may give high profit margins to retailer. As a result, retailers are being aggressively competing with each other in producing their own store brands. However, there are certain authors claim that store brand does not impose any relationship to loyalty especially in store branding products. According to them, people tend to purchase store brand products due to its lower price and not because they are loyal to that brand (Steenkamp \& Dekimpe, 1997; Uncles \& Ellis, 1989). Corstjens \& Lal (2000) noted, during economy downturn, most of consumers are prefer to choose store brand due to its slightly lower price. It is because, at this time their incomes typically dropped and caused them unaffordable to purchase national brand which is much more expensive. However, when the economy recovered, consumers tend to switch back to national brand.

According to Bellizi et al., (1981) and Cunningham et al., (1982), many families reluctant to buy store brand due to the low quality owned by it. Additionally, Elliot (1996), Zeithaml (1988) and Aaker (1991) noted, low price of private label brand usually leads to low quality products delivered. Moreover, Dodds et al., (1991) suggested, price offered by one brand will determine its quality and consumers' willingness to spend money for the product. In the simpler words, consumers are willing to pay for lower price products rather than the higher one and higher price products are considered to have high quality compared to lower price products (Pechmann \& Ratneshwar, 1991).

Conversely, although store brand offers lower price than national brand, it still have the same level of quality as national brand ("Target up \& up Brand Offers Great Quality at Lower Price", 2009; Boyle, 2009). In addition, Dunne and Narasimhan (1999) stated, the quality of store brand is improving from time to time. Moreover, Hoch (1996) added, today, different in price between store brand and national brand in deciding the success of sore brand is no longer debated since it depends on the way retailers distribute the products' quality, not the price (Richardson et al., 1994). Furthermore, Dick et al., (1997) added, the lower price offers by retailers is due to its lower manufacturing cost and lower overhead costs.

There is a positive relationship between store brand and customer loyalty (Nielsen, 1992). Kwon (1990) added, private label brands with superior brand image are more favorable and at the same time generate more loyal customers rather than those with less positive image. It also manipulate customers in choosing good brand (Dolich, 1969) since customers tend to evaluate certain product based on its quality (Sheinin \& Wagner, 2003). In addition, Tepecci (1999) asserted, superior and strong brand image will create products differentiation. Therefore, customers tend to be loyal to products which possessed high differentiation compared to others.

Store brands with good innovation will produce more satisfied customers and eventually will lead to loyalty (Holbrook \& Hughes, 1998). This is because it will create differentiation and increase company's profit (Reda, 2002). Thus, retailers should look for new information on a certain products in order to please consumers' demands (Stamer \& Diller, 2006). However, Aaker and Keller (1990) stressed, if the innovation made does not fulfill consumers' wishes, retailers may not be able to retain brand loyal customers. 
Based on previous study conducted by a few researchers, satisfaction is a significance antecedent of loyalty (Cronin \& Taylor, 1992; Gremler \& Brown, 1997; Fitzell, 1998; Sivadas \& Baker-Prewitt, 2000). Moreover, Rowley (2005) asserted, satisfaction will eventually lead to loyalty with or without the mediating variables. Nonetheless, there are several authors opposed Rowley statement since they suggested few moderators exists between the relationship which are value (Zeithaml, 1988), experience, price (Anderson et al., 1994) and quality (Oliver, 1993).

Besides, Morgan and Hunt (1994), Garbarino and Johnson (1999) and Assael (1987) suggested, commitment plays an important role as the precursor of customer loyalty. In addition, commitment also is used for forecasting customers' future purchase frequency behavior (Dwyer et al., 1987 and Morgan \& Hunt, 1994). Meyer and Allen (1991) and Gundlach et al., (1995) noted, commitment can be categorized into three different types which are affective commitment, calculative commitment and normative commitment. Moreover, Taylor et al., (2004) stated, resistance to change is an essential element influencing commitment and it will finally lead to loyalty.

Furthermore, brand equity also is significantly related to customer loyalty (Aaker, 1991; Ambler, 1997). In addition, there are several variables that may influence brand equity for a certain store brand which are public relation, symbols and packages (Aaker, 1991), firm image, slogans or jingles, warranties (Boulding \& Kirmani, 1993), promotional effect (Keller, 1993), brand-naming strategy (Keller et al., 1998) and promotional effect. Last but not least, Aaker (1991) also added few dimensions of brand equity; brand associations, brand awareness, brand loyalty and perceived quality.

By previous research, trust is positively related to customer loyalty (Berry, 1993; Gremler \& Brown, 1996; Taylor et al., 2004). It influences customers' patronage towards certain brands since it is significantly associated with perceived value and customers' loyalty intention (Guenzi et al., 2009). However, there are few researchers stated that trust is only the mediating factor between satisfaction and loyalty relationship (Singh \& Sirdeshmukh, 2000; Chaudari \& Holbrook, 2001).

Based on Schwendemann (2009), nowadays many store brand products have exceeded the ratings of national brand in the market such as Kroger Mini-Wheats. This situation proved that consumers also are likely to be loyal to store brand. Hale (2010) added, there are five factors which influence customer fulfillment towards store brand; store convenience, store format and variety of selection, effective pricing and value for money, products quality and efficiency of loyalty programs provided.

Additionally, Corstjens \& Lal (2000) stated, the quality of present store brands are equal to national brand. It also has been used as a mechanism for retailers to create product differentiation, maximize their profits and eventually create loyalty among customers. In the other words, although store brands provide lower price to the consumers as compared to national brand, however, the quality delivered is still the same. Thus, it is worth for customers to try (Silverstein, 2010). Furthermore, De Wulf et al., (2005) asserted, store brand does not generate any differences in term of brand equity compared to national brand. It shows that store brand also has its own brand equity which may attract loyal customers.

Moreover, Silverstein noted most of store brands are produced by firms that also producing national brand. Therefore, both of the brands will account the same level of quality. In addition, price differentiation between both brands may be narrowing since national brands realized that it essential for them to lower their prices in order to remain competitive in the market. Besides, customers are willing to spend more money for product which has good brand image regardless of the quality possessed ("Store Brand vs Name Brand", 2010).

Furthermore, Silverstein (2010) opposed what have been said by Corstjens \& Lal (2000) in which people only will buy store brand during recession and switch to national brand when the economy recover. This has been proved by a previous study conducted by Silverstein whereby $93 \%$ of consumers who bought store brand will keep purchasing it although the economy recuperates.

Based on Steenkamp and Dekimpe (1999), Uncles and Ellis (1989) and Corstjens and Lal (2000), customers more prefer to purchase store brand since it offers lower price and usually they not loyal to one brand. However, through our findings, this statement is wrong since we have found that there are other elements potentially influence customer loyalty towards store brand as discussed above. Initially, the situation of our research, we want to ascertain the linkages between store brand and customer loyalty towards store brand in Malaysia. 
Obviously, there is an emergent need for this research in Malaysian retailing industry in order to attract more retailers to join the industry.

Nevertheless, previous researches are still applicable for current practice in order to enhance the knowledge of private label brand. However, this research may be used in certain country that suit to its economic conditions. Eventually, upcoming research should develop the capabilities of store brand in competing with other brands because store brand also can generate higher revenue same as supreme brand. It is hoped that the above discussion will serve as a tool for future research regarding store brands. In addition, this research is beneficial for future work especially as a guideline in conducting primary data research since the research regarding to store brand is limited in Malaysia.

\section{References}

Aaker, D.A. (1991). Managing Brand Equity: Capitalising on the Value of a Brand Name. The Free Press, New York, NY.

Aaker, D.A. (1996). Building Strong Brands. The Free Press, New York, NY.

Aaker, D.A. and Keller, K.L. (1990), Consumer evaluations of brand extensions, Journal of Marketing, 54, pp. 27-41. http://dx.doi.org/10.2307/1252171

Ailawadi, K. (2001). The retail power-performance conundrum: what have we learned? Journal of Retailing, 77, pp. 299-318. http://dx.doi.org/10.1016/S0022-4359(01)00047-1

Ambler, T. (1997). How much of brand equity is explained by trust? Management Decision, 35(4), pp. 283-292. http://dx.doi.org/10.1108/00251749710169666

Anderson, E.W., Fornell, C. \& Lehmann, D.R. (1994). Customer Satisfaction, Market Share and Profitability: Findings from Sweden. Journal of Marketing, 58(July), pp. 53-66. http://dx.doi.org/10.2307/1252310

Assael, H. (1987). Consumer Behavior and Marketing Action, $3^{\text {rd }}$ ed. Boston: PWS-Kent.

Azzato, M. (2009). Store Brands Drive Differentiation and Profit. [Online] Available: http://www.storebrandsdecision.com/news/2009/06/13/store-brands-drives-differentiation-and-profit $\quad\left(30^{\text {th }}\right.$ January 2011)

Bellizzi, J.A., Kruckeberg, H.F., Hamilton, J.R. \& Martin, W.S. (1981). Consumer perceptions of national, private, and generic brands. Journal of Retailing, 57, pp. 56-70.

Berry, L. L. (1993). Playing Fair in Retailing. Arthur Anderson Retailing Issues Newsletter (March), 5, 2.

Biel, A.L. (1993). Converting image into equity, in Aaker, D.A. and Biel, A.L. (Eds), Brand Equity and Advertising. Lawrence Erlbaum Associates, Hillsdale, NJ, pp. 67-82.

Bloemer, J.M.M. \& Kasper, J.D.P. (1995). The Complex Relationship Between Consumer Satisfaction and Brand Loyalty. Journal of Economic Psychology, 16, pp. 311-329. http://dx.doi.org/10.1016/0167-4870(95)00007-B

Blomback, A. \& Axelsson, B. (2007). The role of corporate brand image in the selection of new subcontractors. Journal of Business \& Industrial Marketing, 22(6), pp. 418-430. http://dx.doi.org/10.1108/08858620710780181

Boulding, W. \& Kirmani, A. (1993). A consumer-side experimental examination of signaling theory: do consumers perceive warranties as signals of quality? Journal of Consumer Research, 20(1), pp. 111-123. http://dx.doi.org/10.1086/209337

Boyle, M. (2009). Wal-Mart Gives Its Store Brand a Makeover. [Online] Available: http://www.businessweek.com/bwdaily/dnflash/content/mar2009/db20090316_585298.htm

Buchanan, L., Simmons, C.J. \& Bickart, B.A. (1999). Brand equity dilution: retailer display and context brand effects. Journal of Marketing Research, 36(3), pp. 345-355. http://dx.doi.org/10.2307/3152081

Bullmore, J. (1984). The brand and its image re-visited. International Journal of Advertising, 3(3), pp. 235-8.

Chaudhuri, A. \& Holbrook, M.B. (2001). The chain of effects from brand trust and brand affect to brand performance: the role of brand loyalty. Journal of Marketing, 65(2), pp. 81-93. http://dx.doi.org/10.1509/jmkg.65.2.81.18255 
Churchill, G.A. \& Surprenant, C. (1982). An Investigation into the Determinants of Customer Satisfaction. Journal of Marketing Research, 19(November), pp. 491-504. http://dx.doi.org/10.2307/3151722

Corstjens, M. \& Lal, R. (2000). Building Store Loyalty Through Store Brands: (Statistical Data Included). Journal of Marketing Research.

Cronin, J.J. Jr \& Taylor, S.A. (1992). Measuring service quality: a re-examination and extension. Journal of Marketing, 56(July), pp. 55-68. http://dx.doi.org/10.2307/1252296

Crosby, L.A., Evans, K.R. \& Cowles, D. (1990). Relationship quality in services selling: an interpersonal influence perspective. Journal of Marketing, 54, pp. 68-81. http://dx.doi.org/10.2307/1251817

Cunningham, I.C.M., Hardy, A.P., \& Imperia, G. (1982). Generic brands versus national brands and store brands. Journal of Advertising Research, 22, pp. 25-32.

De Ruyter, K., Moorman, L. \& Lemmink, J. (2001). Antecedents of commitment and trust in customer-supplier relationships in high technology markets. Industrial Marketing Management, 30(3), pp. 271-286. http://dx.doi.org/10.1016/S0019-8501(99)00091-7

De Wulf, K. G., Odekerken-Schroder, F., Goedertier, F. \& Van Ossel, G. (2005). Consumer perceptions of store brands versus national brands. Journal of Consumer Marketing, 22(4), pp. 223-232. http://dx.doi.org/10.1108/07363760510605335

Dick, A., Jain, A. \& Richardson, P. (1997). How consumers evaluate store brands. Pricing Strategy \& Practice, 5(1), pp. 18-24. http://dx.doi.org/10.1108/09684909710155529

Dodds, W.B., Kent, B.M. \& Dhruv, G. (1991). Effect of Price, Brand and Store Information on Buyers' Product Evaluation. Journal of Marketing Research, 28(November), pp. 307-319. http://dx.doi.org/10.2307/3172866

Dolich, I.J. (1969). Congruence relationships between self images and product brands. Journal of Marketing Research, 6(1), pp. 80-4. http://dx.doi.org/10.2307/3150001

Dunne, D. \& Narasimhan, C. (1999). The new appeal of private labels. Harvard Business Review, Vol. 77, No. 3 , pp. 41-52.

Dwyer, F.R., Schurr, P.H. \& Oh, S. (1987). Developing buyer-seller relationships. Journal of Marketing, 51(2), pp. 11-27. http://dx.doi.org/10.2307/1251126

Dyson, P., Farr, A. \& Hollis, N.S. (1996). Understanding, measuring, and using brand equity. Journal of Advertising Research, 36(6), pp. 9-21.

Elliott, T.L. III. (1996). Brand management: what's in store? Telephony, (231)6, pp. 30-5.

Elms, J., Canning, C., Kervenoael, R., Whysall, P. \& Hallsworth, A. (2010). 30 years of retail image: where (and how) do you shop? International Journal of Retail \& Distribution Management, 38(11/12), pp. 817-827. http://dx.doi.org/10.1108/09590551011085920

Farquhar, P. (1989). Managing brand equity. Marketing Research, September, pp. 24-33.

Fournier, S. (1998). Consumers and their brands: developing relationship theory in consumer research. Journal of Consumer Research, 24(4), pp. 343-373. http://dx.doi.org/10.1086/209515

Garbarino, E. \& Johnson, M. (1999). The different roles of satisfaction, trust and commitment in customer relationships. Journal of Marketing, 63(2), pp. 70-87. http://dx.doi.org/10.2307/1251946

Getty, J.M. \& Thompson, K.N. (1994). The relationship between quality, satisfaction and recommending behavior in lodging decision. Journal of Hospitality \& Leisure Marketing, 2(3), pp. 3-22. http://dx.doi.org/10.1300/J150v02n03_02

Geyskens, I., Steenkamp, J., Scheer, L. \& Kumar, N. (1996). The effects of trust and interdependence on relationship commitment: a transatlantic study. International Journal of Research in Marketing, 13(4), pp. 303-317. http://dx.doi.org/10.1016/S0167-8116(96)00006-7

Gonring, M.P. (2008). Customer loyalty and employee engagement: an alignment for value. Journal of Business Strategy, 29(4), pp. 29-40. http://dx.doi.org/10.1108/02756660810887060 
Gremler, D.D. \& Brown, S.W. (1996). Service loyalty: its nature, importance, and implications, in Edwardson, B., Brown, S.W. and Johnston, R. (Eds), Advancing Service Quality: A Global Perspective. International Service Quality Association, pp. 171-180.

Gremler, D.D. \& Brown, S.W. (1997). Service loyalty: its nature, importances and implications. Advancing service quality: a global perspective, in Edvardsson et al. (Eds), Quiz 5 Conference Processing. University of Karlstad, Sweden, pp. 171-181.

Gronroos, C. (1995). From marketing mix to relationship marketing: towards a paradigm shift in Marketing. Management Decision, 32(2), pp. 4-20. http://dx.doi.org/10.1108/00251749410054774

Guenzi, P., Johnson, M.D. \& Castaldo, S. (2009). A comprehensive model of customer trust in two retail stores. Journal of Service Management, 20(3), pp. 290-316. http://dx.doi.org/10.1108/09564230910964408

Gundlach, G.T., Achrol, R.S. \& Mentzer, J.T. (1995). The structure of commitment in exchange. Journal of Marketing, 59(1), pp. 78-92. http://dx.doi.org/10.2307/1252016

Gwinner, K.P., Gremler, D.D. and Bitner, M.J. (1998). Relational benefits in services industries: the customer's perspective. Journal of the Academy of Marketing Science, 26(2), pp. 101-14. http://dx.doi.org/10.1177/0092070398262002

Hale, T. (2010). The Lowest Price Is Not Always the Best Price. [Online] Available: http://blog.nielsen.com/nielsenwire/consumer/the-lowest-price-is-not-always-the-best-price/ (29 $9^{\text {th }}$ March 2011)

Herstein, R. \& Gamliel, E. (2004). An investigation of private branding as a global phenomenon. Journal of Euromarketing, Vol. 13, No. 4, pp. 59-77. http://dx.doi.org/10.1300/J037v13n04_04

Heskett, J.L., Jones, T.O., Loveman, G.W., Sasser, W.E. Jr \& Schlesinger, L.A. (1994). Putting the service profit chain to work. Harvard Business Review, March-April, pp. 105-11.

Hoch, S.J. (1996). How should national brands think about private labels? Sloan Management Review, Winter, pp. 89-102.

Holbrook, J.A.D. \& Hughes, L.P. (1998). Innovation in enterprises in British Columbia, in de La Mothe, J. and Paquet, G. (Eds), Local and Regional Systems of Innovation. Kluwer Academic, Boston, MA.

Holbrook. M.B. (1994). The Nature of Customer Value: An Axiology of Services in the Consumption Experience, in Roland T. Rust and Richard L. Oliver, eds. Service Quality: New Directions in Theory and Practice. Thousand Oaks, CA: Sage Publications, Inc., 21-71.

Huang, Y. \& Huddleston, P. (2009). Retailer premium own-brands: creating customer loyalty through own-brand products advantage,.International Journal of Retail \& Distribution Management, 37(11), pp. 975-992. http://dx.doi.org/10.1108/09590550910999389

Johnson,M.D. \& Puto, C.P. (1987). A review of consumer judgement and choice, in Houston, M. (Ed.), Review of Marketing. American Marketing Association, Chicago, IL, pp. 236-92.

Kandampully, J. \& Suhartanto, D. (2000). Customer loyalty in the hotel industry: the role of customer satisfaction and image. International Journal of Contemporary Hospitality Management, 12(6), pp. 346-351. http://dx.doi.org/10.1108/09596110010342559

Keller, K.L. \& Lehmann, D.R. (2006). Brands and branding: research findings and future priorities. Marketing Science, 25(6), pp. 740-759. http://dx.doi.org/10.1287/mksc.1050.0153

Keller, K.L. (1993). Conceptualizing, measuring, and managing customer-based brand equity. Journal of Marketing, 57(1), pp. 1-22. http://dx.doi.org/10.2307/1252054

Keller, K.L. (1998). Strategic Brand Management: Building, Measuring, and Managing Brand Equity. Prentice Hall, Upper Saddle River, NJ.

Keller, K.L., Heckler, S.E. \& Houston, M.J. (1998). The effects of brand name suggestiveness on advertising recall. Journal of Marketing, 62(1), pp. 48-57. http://dx.doi.org/10.2307/1251802

Kwon, Y. (1990). Brand name awareness and image perception of women's daytime apparel. Perceptual and Motor Skills, 71, pp. 743-52. http://dx.doi.org/10.2466/pms.1990.71.3.743 
LaBarbera, P.A. \& Mazursky, D. (1983). A longi-tudinal assessment of consumer satisfaction/ dissatisfaction: the dynamic aspect of the cognitive process. Journal of Marketing Research, 20, pp. 393-404. http://dx.doi.org/10.2307/3151443

Martenson, R. (2007). Corporate brand image, satisfaction and store loyalty: A study of the store as a brand, store brands and manufacturer brand. International Journal of Retail \& Distribution Management, 35(7), pp. 544-555. http://dx.doi.org/10.1108/09590550710755921

Meyer, J.P. \& Allen, N.J. (1991). A three-component conceptualization of organizational commitment. Human Resource Management Review, 1(1), pp. 61-89. http://dx.doi.org/10.1016/1053-4822(91)90011-Z

Monroe, K. B. (1990). Pricing Making Profitable Decisions. New York: McGraw Hill Publishing Company. http://dx.doi.org/10.2307/1252308

Morgan, R.M. \& Hunt, S.D. (1994). The commitment-trust theory of relationship marketing. Journal of Marketing, 58(3), pp. 20-38.

Nielsen, A.C. (1992). Category Management: Positioning your Organization to Win. NTC Business Books, Chicago, IL.

Nielsen, A.C. (2005). Trade promotion practices report. [Online] available: http://store.vnuemedia.com/acn/store/index.jsp

Oliva, T.A., Oliver, R.L. \& MacMillan, I.C. (1992). A catastrophe model for developing service satisfaction strategies. Journal of Marketing, 56(July), pp. 83-95. http://dx.doi.org/10.2307/1252298

Oliver, R.L. (1993). A Conceptual Model of Service Quality and Service Satisfaction. in Teresa A. Swartz, David E. Bowen and Stephen W. Brown, eds. Advances in Services Marketing and Management. Greenwich, CT:JAI Press, 65-86.

Oliver, R.L. (1997). Satisfaction: A Behavioral Perspective on the Consumer. Irwin/McGraw-Hill, New York, NY.

Osman, M.Z. (1983). A conceptual model of retail image influence on loyalty patronage behavior. International Review of Retail, Distribution \& Consumer Research, 3(2), pp. 133-48. http://dx.doi.org/10.1080/09593969300000011

Palumbo, F., \& Herbig, P. (2000). The multicultural context of brand loyalty. European Journal of Innovation Management, 3(3), pp. 116-124. http://dx.doi.org/10.1108/14601060010334876

Pappu, R., Quester, P.G. \& Cooksey, R.W. (2007). Country image and consumer-based brand equity: relationships and implications for international marketing. Journal of International Business Studies, 38(5), pp. 726-745. http://dx.doi.org/10.1057/palgrave.jibs. 8400293

Patterson, M. (1999). Re-appraising the concept of brand image. Journal of Brand Management, 6(6), pp. 409-426.

Pechmann, C. \& Ratneshwar, S. (1991). Consumer covariation judgements: theory or data driven? Journal of Consumer Research, 19(3), pp. 373-386. http://dx.doi.org/10.1086/209308

Pepe, M.S., Abratt, R. \& Dion, P. (2011). The impact of private label brands on customer loyalty and product category profitability. Journal of Product \& Brand Management, 20(1), pp. 27-36. http://dx.doi.org/10.1108/10610421111107996

Pettijohn, L.S., Mellott, D.W. \& Pettijohn, C.E. (1992). The relationship between retailer image and brand image. Psychology \& Marketing, 9(4), pp. 311-328. http://dx.doi.org/10.1002/mar.4220090405

Reda, S. (2002). Department stores struggle to reinvent troubled model. Stores, 84(7), pp. 22.

Reichheld, F.F. (1996). The Loyalty Effect. Harvard Business School Press, Boston, MA.

Reichheld, F.F., \& Sasser, W.E. (1990). Zero defections: quality comes to services. Harvard Business Review, September-October, pp. 105-111.

Richardson, P.S., Dick A.S. \& Jain, A.K. (1994). Extrinsic and intrinsic cue effects on perceptions of store brand quality. Journal of Marketing, Vol. 58 No. 4, pp. 28-36. http://dx.doi.org/10.2307/1251914 
Ross-Wooldridge, B., Brown, M.P. \& Minsky, B.D. (2004). The role of company image as brand equity. Corporate Communications, 9(2), pp. 159-167. http://dx.doi.org/10.1108/13563280410534357

Rowley, J. (2005). The four Cs of customer loyalty. Marketing Intelligence \& Planning, 23(6), pp. 574-581. http://dx.doi.org/10.1108/02634500510624138

Rowley, J. (2005). The four Cs of customer loyalty. Marketing Intelligence \& Planning, 23(6), pp. 574-81. http://dx.doi.org/10.1108/02634500510624138

Schiffman, L. \& Kanuk, L. (1991). Consumer Behavior. Prentice-Hall, Englewood Cliffs, NJ.

Schutte, T.F. (1969). The semantics of branding. Journal of Marketing, 33, pp. 5-11. http://dx.doi.org/10.2307/1249395

Schwendemann, E. (2009). Store Brand vs. Name Brand-When to Go Cheap. [Online] Available: http://lifehacker.com/\#!5282987/store-brand-vs-name-brandwhen-to-go-cheap

Sewell, D. (2010). Kroger makes push into store-brand beauty products. [Online] Available: http://abcnews.go.com/Business/wireStory?id=11394131

Sheinin, D.A. \& Wagner, J. (2003). Pricing store brands across categories and retailers. Journal of Product \& Brand Management, 12(4), pp. 201-219. http://dx.doi.org/10.1108/10610420310485023

Silverstein, B. (2010). Store Brands Give Name Brands a Run for the Money. [Online] Available: http://www.brandchannel.com/home/post/2010/09/08/Consumer-Reports-Store-Brands-vs-Name-Brands.aspx (28th March 2011)

Singh, J. \& Sirdeshmukh, D. (2000). Agency and trust mechanisms in consumer satisfaction and loyalty judgments. Journal of the Academy of Marketing Science, 28(1), pp. 150-167. http://dx.doi.org/10.1177/0092070300281014

Sivadas, E. \& Baker-Prewitt, J. (2000). An examination of the relationship between service quality, customer satisfaction, and store loyalty. International Journal of Retail \& Distribution Management, 28 (2), pp. 73-82. http://dx.doi.org/10.1108/09590550010315223

Stamer, H. \& Diller, H. (2006). Price segment stability in consumer goods categories. The Journal of Product \& Brand Management, 15(1), pp. 62-72. http://dx.doi.org/10.1108/10610420610650882

Steenkamp, J. B. \& Dekimpe, M. G. (1997). The increasing power of store brands: Building loyalty and market share. Long Range Planning, 30(6), pp. 917-930. http://dx.doi.org/10.1016/S0024-6301(97)00077-0

Store Brand Vs Name Brand. (2010). [Online] Available: http://amateurassetallocator.com/2010/02/23/store-brand-vs-name-brand/ (28 $8^{\text {th }}$ March 2011)

Szymanski, D.M. \& Henard, D.H. (2001). Customer satisfaction: a meta-analysis of the empirical evidence. Journal of the Academy of Marketing Science, 29(1), pp. 16-35.

Tajeddini, K. (2011). The effects of innovativeness on effectiveness and efficiency. Contemporary Middle Eastern Issues, 4(1), pp. 6-18. http://dx.doi.org/10.1108/17537981111111238

Target up \& up Brand Offers Great Quality at Low Prices. (2009). [Online] Available: http://pressroom.target.com/pr/news/up-and-up-release.aspx (7th February 2011)

Taylor, S.A., Celuch, K. \& Godwin, S. (2004). The importance of brand equity to customer loyalty. Journal of Product \& Brand Management, 13(4), pp. 217-227. http://dx.doi.org/10.1108/10610420410546934

Tepeci, M. (1999). Increasing brand loyalty in the hospitality industry. International Journal of Contemporary Hospitality Management, 11(5), pp. 223-29. http://dx.doi.org/10.1108/09596119910272757

Uncles, M. \& Ellis, K. (1989). The buying of own labels. European Journal of Marketing, 23(3), pp. 57-70. http://dx.doi.org/10.1108/EUM0000000000561

Uncles, M.D., Dowling, G.R. \& Hammond, K. (2003). Customer loyalty and customer loyalty programs. Journal of Consumer Marketing, 20(4), pp. 294-316. http://dx.doi.org/10.1108/07363760310483676 
Veloutsou, C., Gioulistanis, E. \& Moutinho, L. (2004). Own labels choice criteria and perceived characteristics in Greece and Scotland: factors influencing the willingness to buy. Journal of Product \& Brand Management, 13(4), pp. 228-41. http://dx.doi.org/10.1108/10610420410546943

Waarden, L.M. (2006). The influence of loyalty programme membership on customer purchase behavior. European Journal of Marketing, 42(1/2), pp. 87-114. http://dx.doi.org/10.1108/03090560810840925

Westbrook, R.A. (1980). Intrapersonal Affective Influences upon Consumer Satisfaction with Products. Journal of Consumer Research, 7(June), pp. 49-54. http://dx.doi.org/10.1086/208792

Woodruff, R.B., Ernest, R.C. \& Roger, L.J. (1983). Modelling Consumer Satisfaction Processes Using Experience-Based Norms. Journal of Marketing Research, 20(August), pp. 296-304. http://dx.doi.org/10.2307/3151833

Yasin, N.M., Noor, M.N. \& Mohamad, O. (2007). Does image of country-of-origin matter to brand equity? Journal of Product \& Brand Management, 16(1), pp. 38-48. http://dx.doi.org/10.1108/10610420710731142

Yen, H. J. B., \& Gwinner, K.P. (2003). Internet retail customer loyalty: the mediating role of relational benefits. International Journal of Service Management, 14(5), pp. 483-500. http://dx.doi.org/10.1108/09564230310500183

Yoo, B., Donthu, N. \& Lee, S.H. (2000). An examination of selected marketing mix elements and brand equity. Journal of the Academy of Marketing Science, 28(2), pp. 195-211. http://dx.doi.org/10.1177/0092070300282002

Zeithaml, V.A. (1988). Consumer Perceptions of Price, Quality and Value: A Means-End Model and Synthesis of Evidence. Journal of Marketing, 52(July), pp. 2-22. http://dx.doi.org/10.2307/1251446 